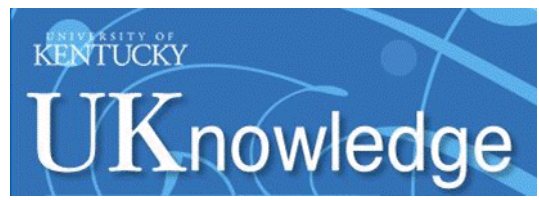

University of Kentucky

UKnowledge

8-11-2014

\title{
A Non-Destructive Method for Measuring the Mechanical Properties of Ultrathin Films Prepared by Atomic Layer Deposition
}

\author{
Qinglin Zhang \\ University of Kentucky, qinglinzhang@uky.edu \\ Xingcheng Xiao \\ General Motors Global Research and Development Center \\ Yang-Tse Cheng \\ University of Kentucky, yang.t.cheng@uky.edu \\ Mark W. Verbrugge \\ General Motors Global Research and Development Center
}

Follow this and additional works at: https://uknowledge.uky.edu/cme_facpub

Part of the Chemical Engineering Commons, and the Materials Science and Engineering Commons Right click to open a feedback form in a new tab to let us know how this document benefits you.

\section{Repository Citation}

Zhang, Qinglin; Xiao, Xingcheng; Cheng, Yang-Tse; and Verbrugge, Mark W., "A Non-Destructive Method for Measuring the Mechanical Properties of Ultrathin Films Prepared by Atomic Layer Deposition" (2014). Chemical and Materials Engineering Faculty Publications. 6.

https://uknowledge.uky.edu/cme_facpub/6

This Article is brought to you for free and open access by the Chemical and Materials Engineering at UKnowledge. It has been accepted for inclusion in Chemical and Materials Engineering Faculty Publications by an authorized administrator of UKnowledge. For more information, please contact UKnowledge@lsv.uky.edu. 


\section{A Non-Destructive Method for Measuring the Mechanical Properties of Ultrathin Films Prepared by Atomic Layer Deposition}

Digital Object Identifier (DOI)

http://dx.doi.org/10.1063/1.4892539

Notes/Citation Information

Published in Applied Physics Letters, v. 105, no. 6, article 061901, p. 1-4.

Copyright 2014 American Institute of Physics. This article may be downloaded for personal use only. Any other use requires prior permission of the author and the American Institute of Physics.

The following article appeared in Applied Physics Letters, v. 105, no. 6, article 061901, p. 1-4 and may be found at http://dx.doi.org/10.1063/1.4892539. 


\title{
A non-destructive method for measuring the mechanical properties of ultrathin films prepared by atomic layer deposition
}

\author{
Qinglin Zhang, ${ }^{1,2}$ Xingcheng Xiao, ${ }^{1, a)}$ Yang-Tse Cheng, ${ }^{2}$ and Mark W. Verbrugge ${ }^{1}$ \\ ${ }^{1}$ General Motors Global Research and Development Center, Warren, Michigan 48090, USA \\ ${ }^{2}$ Department of Chemical and Materials Engineering, University of Kentucky, Lexington, \\ Kentucky 40506-0046, USA
}

(Received 29 May 2014; accepted 26 July 2014; published online 11 August 2014)

\begin{abstract}
The mechanical properties of ultrathin films synthesized by atomic layer deposition (ALD) are critical for the liability of their coated devices. However, it has been a challenge to reliably measure critical properties of ALD films due to the influence from the substrate. In this work, we use the laser acoustic wave (LAW) technique, a non-destructive method, to measure the elastic properties of ultrathin $\mathrm{Al}_{2} \mathrm{O}_{3}$ films by ALD. The measured properties are consistent with previous work using other approaches. The LAW method can be easily applied to measure the mechanical properties of various ALD thin films for multiple applications. (C) 2014 AIP Publishing LLC.

[http://dx.doi.org/10.1063/1.4892539]
\end{abstract}

Atomic layer deposition (ALD) is a thin film preparation technique, where the film is grown layer-by-layer. Since it is a self-limiting surface reaction process which involves alternatively inputting different precursors each cycle, the thickness of ALD coating can be precisely controlled by the cycle number. ${ }^{1,2}$ Since the gaseous precursors can reach any exposed surface, thin films can be deposited on nearly any shape and geometry. ${ }^{1,3}$ ALD has been used to deposit oxides (e.g., $\mathrm{Al}_{2} \mathrm{O}_{3}, \mathrm{HfO}_{2}, \mathrm{TiO}_{2}, \mathrm{ZnO}$ ), ${ }^{4}$ sulfides (e.g., $\mathrm{ZnS}, \mathrm{SrS}$ ), ${ }^{5,6}$ fluorides (e.g., $\left.\mathrm{CaF}_{2}, \mathrm{LaF}_{3}\right)^{7}$ metals (e.g., Ir, $\left.\mathrm{Pt}\right)^{8}$ and polymers (e.g., pyromellitic dianhydride (PMDA)) ${ }^{9}$ the nature of ALD coatings strongly depends on the precursors selected. ALD has been widely used in various applications, for instance, high- $k$ gate oxides,${ }^{10}$ passivation of crystal silicon solar cell, ${ }^{11}$ coating of nanoporous structures, ${ }^{6,12}$ metal coating for fuel cell catalyst layers, ${ }^{13}$ and adhesion layers. ${ }^{14}$ In the microelectronics industry, ALD has enabled the rapid development towards scaling down device size, improving performance, functionality, and reliability. For example, the mechanical properties are critical for high- $k$ dielectrics. The elastomechanical response to thermal cycling can significantly influence the compatibility and long term reliability. ${ }^{15}$ In the past 5 years, ALD has been employed for surface modification of components in lithium ion batteries (LIBs), including negative and positive electrodes, and separators, to mitigate the undesirable side reactions and increase battery life. ${ }^{16}$

In addition to electrical and ionic conductivities, the mechanical properties of the ultrathin thin films are believed important for LIB applications. However, the mechanical properties of ALD films may be different from their bulk counterparts because the differences in synthesis methods, material structures, and the surface area to volume ratio. An objective for the use ALD coatings on lithium ion battery electrodes is to suppress electrolyte reduction as well as to stabilize the inherent solid electrolyte interphase (SEI) layer that form during cell operation, thereby suppressing

\footnotetext{
${ }^{\text {a) }}$ Author to whom correspondence should be addressed. Electronic mail: xingcheng.xiao@gm.com
}

mechanical fracture in the electrode, which can be problematic for high lithium-capacity materials, such as Si and Sn. Specifically, $\mathrm{ALD} \mathrm{Al}_{2} \mathrm{O}_{3}$ was found to increase the performance and durability of silicon electrodes, though $\mathrm{Al}_{2} \mathrm{O}_{3}$ is a known electrical insulator. ${ }^{17}$ Understanding the elastic properties of thin films is, therefore, indispensable for designing the electrode coatings for high energy electrode materials with large volume change (over 300\%) and internal stress during lithiation and delithiation. ${ }^{17}$

Nanoindentation (NI) has been applied to obtain the elastic modulus of ALD thin films. ${ }^{18}$ NI tests require the depth of indents to be less than $1 / 10$ of the film thickness to neglect the influence of the substrate. For such studies, the ALD films need to be thick, such as $300 \mathrm{~nm}$. The effective deposition rate (thickness increment per time unit) of ALD is low. Films of $300 \mathrm{~nm}$ require approximately 2000 reaction cycles which can lead to a time consuming (over $5 \mathrm{~h}$ ) and precursor wasting process. Other testing methods, such as bulge testing and pointers, ${ }^{19}$ require either thick films or complicated substrates.

In this work, elastic properties of ALD alumina thin coatings were characterized by laser acoustic wave (LAW) method. LAW is a non-destructive sonic technique to obtain the mechanical properties of thin films. Surface acoustic waves (SAWs) propagate parallel to the surface measured with penetration depths as thin as $1 / 100$ of the wavelength. ${ }^{20}$ Hence, SAWs are suitable for determining the elastic properties of very thin films. It has been applied to coatings such as diamond like carbon (DLC) and silicon nitride. ${ }^{21,22} \mathrm{We}$ show that the LAW technique, along with other characterization methods, is capable of measuring the elastic properties of thin ALD films as thin as a few nanometers in a straightforward manner.

$\mathrm{Al}_{2} \mathrm{O}_{3}$ thin coatings were grown on (100) $\mathrm{Si}$ wafer (etched with $10 \% \mathrm{HF}$ water solution to reduce the influence of native $\mathrm{SiO}_{\mathrm{x}}$ surface species). Trimethylaluminium (TMA) and high performance liquid chromatography (HPLC) waters were used as precursors in the ALD system. The pulse time is $0.015 \mathrm{~s}$, exposure time is $2 \mathrm{~s}$, and purging time is $8 \mathrm{~s}$ for both precursors. The growth temperature is chosen as $120^{\circ} \mathrm{C}$ 
for LIB applications because higher temperatures lead to the damage of polymer binders in the electrode and lower temperatures lead to poor film quality. The thickness of $\mathrm{Al}_{2} \mathrm{O}_{3}$ films were controlled by cycle numbers, ranging from 50 to 250 cycles.

Elastic modulus is very sensitive to the structure of material. The velocity $(c)$ of SAW is related to elastic modulus $E$, Poisson's ratio $v$, and density $\rho$ :

$$
c=\frac{0.87+1.12 v}{1+v} \sqrt{\frac{E}{2 \rho(1+v)}} .
$$

By generating different frequencies of sound waves, the modulus can be fitted with the predetermined density, thickness, and Poisson's ratio. The depth of the SAW is proportional to the wave length: for example, higher frequencies lead to smaller penetration depths by the acoustic waves. The phase velocity is frequency dependent and is influenced by the substrate and the film; however, the film contribution dominates at high frequencies. The relation between frequency and phase velocity (called dispersion relation) was measured using a commercial LAW instrument (Fraunhofer Nanotech). Elastic properties of the films can then be obtained from the dispersion relation using the aforementioned model by the least square method. Details can be found in Refs. 20, 21, and 23 (Illustrated by Figure 2 in Ref. 20). In order to obtain the right elastic properties of thin films using LAW, thickness and density need to be measured with other techniques independently as the inputs for LAW Analyzer.

In this work, the thickness and density of thin films were obtained using the $\mathrm{X}$-ray reflectivity (XRR) technique. ${ }^{24}$ XRR was performed with a Bruker D8 ADVANCE system with two theta varying from $0^{\circ}$ to $8^{\circ}$. The $\mathrm{X}$-ray wavelength from $\mathrm{Cu} K \alpha$ was $0.154 \mathrm{~nm}$. The voltage and electron beam current were controlled at $40 \mathrm{kV}$ and $20 \mathrm{~mA}$, respectively. Thickness and density were then obtained by fitting the XRR data using Bruker Leptos software. Electron probe microanalysis (EPMA model SX 100 by CAMECA Instruments Inc.) was used to verify the density of ALD films. Data were collected in static and in scanning mode over a $30 \mu \mathrm{m}$ area at 10 different positions in the sample. The electron beam conditions were $20 \mathrm{kV}$ and $20 \mathrm{nA}$. The $\mathrm{Si}, \mathrm{Al}$, and $\mathrm{O} \mathrm{x}$-ray intensities from the samples and standards (pure $\mathrm{Al}$, pure $\mathrm{Si}$, and $\mathrm{SrTiO}_{3}$ ) were used to estimate the area density of the $\mathrm{Al}_{2} \mathrm{O}_{3}$ coating on the Si substrate using thin film modeling program GMRFILM. $^{25}$

Figure 1 shows the thickness and density of all films with 50 to 250 ALD cycles. The blue dots show the thicknesses of ALD alumina films ranging from $7.6 \mathrm{~nm}$ to $37.9 \mathrm{~nm}$ by XRR, corresponding to 50 to 250 reaction cycles. The average growth rate is $1.5 \AA$ /cycle. The linear relation is shown as the dashed line. By fitting the XRR data, the thickness and density are estimated simultaneously. The density ranges from 3.1 to $3.4 \mathrm{~g} / \mathrm{cm}^{3}$ with an average density of $3.26 \mathrm{~g} / \mathrm{cm}^{3}$ (triangles in Figure 1). EPMA is also used to estimate the density for sample with 250 reaction cycles. The area density obtained is $11.8 \pm 0.2 \mu \mathrm{g} / \mathrm{cm}^{2}{ }^{26}$ By inputting the thickness information obtained from XRR $(37.9 \mathrm{~nm})$, we are able to estimate the density of the film. The density

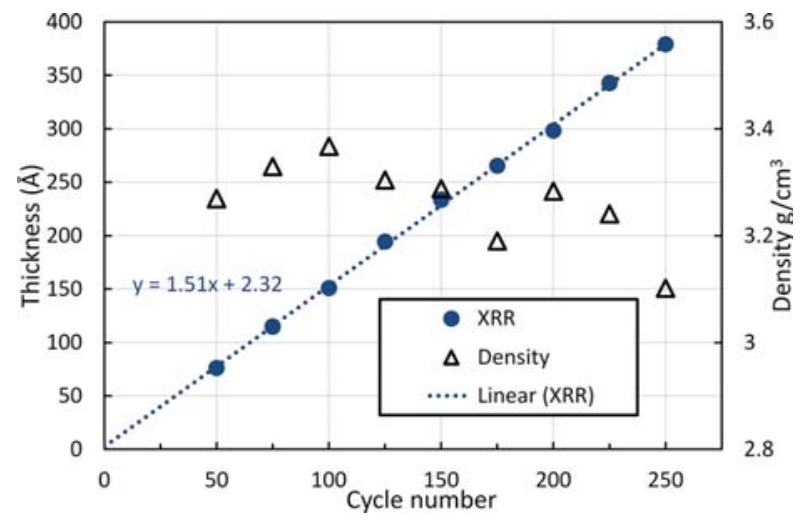

FIG. 1. Thickness of $\mathrm{ALD} \mathrm{Al}_{2} \mathrm{O}_{3}$ films. The thicknesses correspond to $50-250$ reaction cycles and vary from $7.6 \mathrm{~nm}-37.9 \mathrm{~nm}$ as determined by XRR (filled circles). The growth rate is $1.51 \AA /$ cycle (constant growth rate). Dashed line corresponds to the fit results to the XRR thickness data; triangles are measured density by XRR for all films, with an average density of $3.26 \mathrm{~g} / \mathrm{cm}^{3}$; the density does not change much with the thickness/cycle number.

extracted by EPMA is $3.11 \mathrm{~g} / \mathrm{cm}^{3}$, which matches well with the XRR results (Table I). Both thickness (growth rate) and density match well with previous ALD work. ${ }^{24}$ EPMA also provides the composition information about the sample. The sample contains $44.8 \%$ of $\mathrm{Al}$ and $55.2 \%$ of $\mathrm{O}$ in terms of atomic percent. The low concentration of $\mathrm{O}$ is consistent with oxygen deficiency. Previous studies show that the $\mathrm{O}$ vacancies in ALD amorphous films have similar parameters in crystalline $\alpha-\mathrm{Al} 2 \mathrm{O} 3$ and $\gamma-\mathrm{Al}_{2} \mathrm{O}_{3}{ }^{27}$

In our experiments, the use of single crystal silicon substrate enables us to obtain the phase velocity accurately for ultra-thin films $(t<20 \mathrm{~nm})$. Other polycrystalline substrates, such as steel, can cause ultrasonic scattering and reduce the sensitivity of the measurements. ${ }^{28}$

Figure 2 shows the dispersion relation (phase velocity versus frequency) for all films. The number on up-right corner of each figure is the reaction cycle number. As would be expected, for the pure silicon substrate, the phase velocity of SAW does not change significantly with frequency range of 50 to $230 \mathrm{MHz}$. All the diagrams in Figure 2 show that the alumina films decrease the phase velocity with increasing frequency. The phase velocity decreases faster with increasing alumina thickness. As described previously, the phase velocity is dependent on elastic properties, density of both substrate and film, and the thickness of the film; and film thickness and density can be determined by XRR and

TABLE I. Summary of the properties of different alumina ALD films.

\begin{tabular}{lcccc}
\hline \hline $\begin{array}{l}\text { Cycle } \\
\text { number }\end{array}$ & $\begin{array}{c}\text { Thickness } \\
(\mathrm{nm})\end{array}$ & $\begin{array}{c}\text { Growth } \\
\text { rate }(\AA / \mathrm{s})\end{array}$ & $\begin{array}{c}\text { Density } \\
\left(\mathrm{g} / \mathrm{cm}^{3}\right)\end{array}$ & $\begin{array}{c}\mathrm{E} \\
(\mathrm{GPa})\end{array}$ \\
\hline 250 & 37.91 & 1.52 & 3.10 & $171.22 \pm 1.04$ \\
225 & 34.29 & 1.52 & 3.24 & $172.86 \pm 0.72$ \\
200 & 29.84 & 1.49 & 3.28 & $177.96 \pm 0.88$ \\
175 & 26.53 & 1.52 & 3.19 & $171.34 \pm 0.68$ \\
150 & 23.37 & 1.56 & 3.29 & $175.63 \pm 0.88$ \\
125 & 19.45 & 1.56 & 3.30 & $170.42 \pm 1.67$ \\
100 & 15.09 & 1.51 & 3.37 & $175.76 \pm 1.05$ \\
75 & 11.49 & 1.53 & 3.33 & $175.21 \pm 2.15$ \\
50 & 7.62 & 1.52 & 3.27 & $160.56 \pm 2.96$ \\
\hline \hline
\end{tabular}



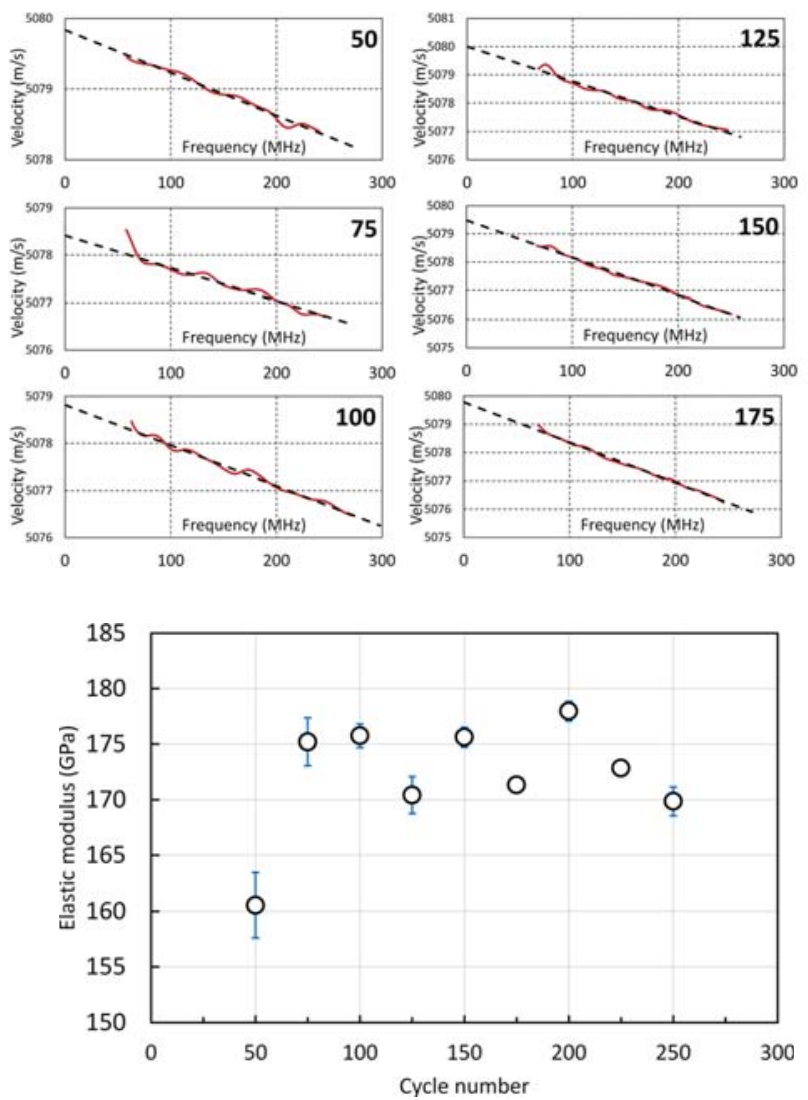

FIG. 3. Elastic modulus obtained from LAW. Except the thinnest film, 50 cycles $(7.6 \mathrm{~nm})$, the modulus is similar for all films and varies from 170 to $180 \mathrm{GPa}$.

EPMA. The elastic properties of substrate are provided in Table S1. ${ }^{26}$ The values agree well with published values. The density of Si substrate is $2.33 \mathrm{~g} / \mathrm{cm}^{3}$. Poisson's ratio of $\mathrm{Si}$ is 0.22 , and that of alumina is 0.21 . With these parameters, we are able to obtain the elastic modulus of the films by fitting the model (dashed line) to the experiment data (solid line). The elastic modulus is shown in Figure 3 and Table I. The thinnest film, with 50 reaction cycles $(7.6 \mathrm{~nm}$ thick), shows slightly lower elastic modulus. The other modulus values range between 170 and $180 \mathrm{GPa}$, there is no significant change of elastic modulus with increasing the thickness of film. The last row of Table I shows the extracted modulus for the substrate. The values are close to measured and theoretical values for single-crystal $\mathrm{Si}$.

According to our measurement of alumina ALD films ranging from 7.6 to $37.9 \mathrm{~nm}$, there are no obvious trends of
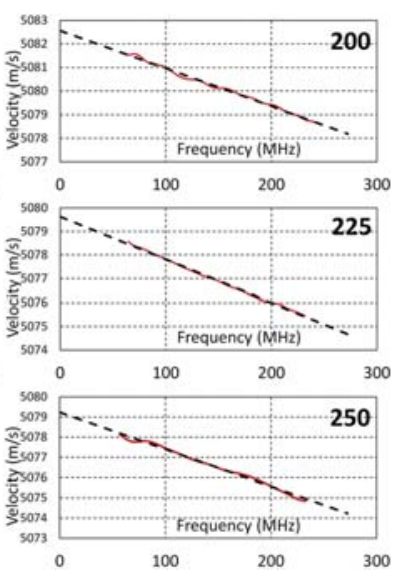

elastic properties, density, or growth rate varying with thickness, which indicates that the structure of the ALD films is substantially invariant. The thickness range we measured cannot be used to revel the material properties at the Sialumina interface, as the interfacial transition layer is only a few atomic layers (usually less than $5 \AA$ ), and the thinnest ALD film we can measure is about $80 \AA$. We expect that the interfacial zone is less than $10 \%$ of the total measured film thickness. We are unaware of an experimental technique that enables one to extract elastic properties of films less than $1 \mathrm{~nm}$ in thickness.

The elastic modulus values obtained in this work are comparable with literature values. Higher ALD deposition temperatures will produce stiffer films (cf. Table II). As mentioned, nanoindentation usually requires films thicker than $100 \mathrm{~nm}$ as the indent depth should within $1 / 10$ of the film thickness to neglect the influence of the substrate. If nanoindentation is used to obtain elastic modulus for films thinner than 100 nanometers, both continuous stiffness measurement and modeling are necessary. The nanobeam deflection method requires a complicated sample fabrication. The films we measured using the LAW method, thickness ranging from $7.8 \mathrm{~nm}$ (50 reaction cycles) to $38 \mathrm{~nm}$ (250 reaction cycles), are much thinner than prior work. The measurement is simple and fast, as well as non-destructive. This method can be applied to most ALD films to obtain the elastic properties.

The density of ALD alumina films $\left(\sim 3.2 \mathrm{~g} / \mathrm{cm}^{3}\right)$ is lower than reported crystal density $\left(3.9-4.1 \mathrm{~g} / \mathrm{cm}^{3}\right)$ and amorphous density $\left(3.5-3.7 \mathrm{~g} / \mathrm{cm}^{3}\right)$ for $\mathrm{Al}_{2} \mathrm{O}_{3},{ }^{29}$ due to the low deposition temperature. This agrees with the previous study of ALD. ${ }^{24}$ The EPMA results show a relative low concentration

TABLE II. Summary of elastic modulus of different alumina ALD film in literature and this work.

\begin{tabular}{lccc}
\hline \hline Deposition temperature $\left({ }^{\circ} \mathrm{C}\right)$ & Thickness $(\mathrm{nm})$ & Testing method & Elastic modulus $(\mathrm{GPa})$ \\
\hline 300 & 60 & Nanoindentation $^{\mathrm{a}}$ & $220 \pm 40$ \\
177 & 300 & Nanoindentation & $180 \pm 8.2$ \\
177 & 100 & Nanobeam deflection & $168 \pm 8$ \\
177 & 50 & Nanobeam deflection & $18 \pm 32$ \\
120 & 7.62 & LAW & $190.56 \pm 2.96$ \\
120 & $11.5-38$ & LAW & $170-180$ \\
100 & 300 & Nanoindentation & This work \\
\hline \hline
\end{tabular}

${ }^{\mathrm{a} C}$ Continuous stiffness method combined with simulation results. 
of oxygen, indicating the oxygen deficiency. That leads to the lower modulus values, 170 to $180 \mathrm{GPa}$, as compared to single crystal $\mathrm{Al}_{2} \mathrm{O}_{3}(530 \mathrm{GPa})^{30}$ and the ceramics (344.83 to $408.99 \mathrm{GPa}) .^{29}$ However, a lower modulus is favorable in many cases. For example, low modulus coatings can usually better accommodate the volume change of the substrate material, particularly for Si based high capacity electrode materials in lithium ion batteries.

In this work, we develop and implement a non-distractive method to obtain the mechanical properties of ultra-thin ALD films. The mechanical properties are critical for multiple applications. We used ALD alumina coatings to demonstrate the approach. With the LAW technique, along with XRR and EPMA, we are able to extract the mechanical properties of ALD films as thin as a few nanometers. The elastic modulus was found to be relatively constant for thicknesses ranging from 7.6 to $37.9 \mathrm{~nm}$, corresponding to 50 to 250 ALD reaction cycles. The methods described in this work can be widely used in determining the elastic properties of thin films.

Q. Zhang is grateful for General Motors' summer internship program. The authors also acknowledges the support by the Assistant Secretary for Energy Efficiency and Renewable Energy, Vehicle Technologies Office of the U.S. Department of Energy under Contract No. DE-AC0205CH11231, subcontract No. 7056410 under the Batteries for Advanced Transportation Technologies (BATT) Program. This project is also partial supported by National Science Foundation CMMI 1000726. We appreciate the help from Lars Haubold (Fraunhofer USA, Lansing, MI) for helping with the LAW system and Dr. Daad B Haddad (General Motors) for EPMA measurements.

${ }^{1}$ M. Leskelä and M. Ritala, Thin solid films 409(1), 138 (2002).

${ }^{2}$ S. M. George, Chem. Rev. 110(1), 111 (2009).

${ }^{3}$ A. C. Jones and M. L. Hitchman, Chemical Vapour Deposition: Precursors, Processes and Applications (Royal Society of Chemistry, 2009).

${ }^{4}$ M. M. Frank, G. D. Wilk, D. Starodub, T. Gustafsson, E. Garfunkel, Y. J. Chabal, J. Grazul, and D. A. Muller, Appl. Phys. Lett. 86(15), 152904 (2005); B. J. Choi, D. S. Jeong, S. K. Kim, C. Rohde, S. Choi, J. H. Oh, H. J. Kim, C. S. Hwang, K. Szot, and R. Waser, J. Appl. Phys. 98(3), 033715 (2005); A. Yamada, B. Sang, and M. Konagai, Appl. Surf. Sci. 112, 216 (1997); D. M. Hausmann, E. Kim, J. Becker, and R. G. Gordon, Chem. Mater. 14(10), 4350 (2002).

${ }^{5}$ J. S. King, C. W. Neff, C. J. Summers, W. Park, S. Blomquist, E. Forsythe, and D. Morton, Appl. Phys. Lett. 83, 2566 (2003).

${ }^{6}$ M. Knez, K. Nielsch, and L. Niinistö, Adv. Mater. 19(21), 3425 (2007).

${ }^{7}$ T. Pilvi, K. Arstila, M. Leskelä, and M. Ritala, Chem. Mater. 19(14), 3387 (2007); M. Ylilammi and T. Ranta-aho, J. Electrochem. Soc. 141(5), 1278 (1994).

${ }^{8}$ T. Aaltonen, M. Ritala, Y.-L. Tung, Y. Chi, K. Arstila, K. Meinander, and M. Leskela, J. Mater. Res. 19(11), 3353 (2004); J. S. King, A. Wittstock,
J. Biener, S. O. Kucheyev, Y. M. Wang, T. F. Baumann, S. K. Giri, A. V. Hamza, M. Baeumer, and S. F. Bent, Nano Lett. 8(8), 2405 (2008).

${ }^{9}$ M. Putkonen, J. Harjuoja, T. Sajavaara, and L. Niinistö, J. Mater. Chem. 17(7), 664 (2007).

${ }^{10}$ M.-H. Cho, Y. S. Roh, C. N. Whang, K. Jeong, S. W. Nahm, D.-H. Ko, J. H. Lee, N. I. Lee, and K. Fujihara, Appl. Phys. Lett. 81(3), 472 (2002); L. Niinistö, M. Nieminen, J. Päiväsaari, J. Niinistö, and M. Putkonen, Phys. Status Solidi A 201(7), 1443 (2004).

${ }^{11}$ J. Schmidt, A. Merkle, R. Brendel, B. Hoex, M. C. M. Van de Sanden, and W. M. M. Kessels, Prog. Photovoltaics: Res. Appl. 16(6), 461 (2008); B. Hoex, S. B. S. Heil, E. Langereis, M. C. M. Van de Sanden, and W. M. M. Kessels, Appl. Phys. Lett. 89(4), 042112 (2006).

${ }^{12}$ J. W. Elam, D. Routkevitch, P. P. Mardilovich, and S. M. George, Chem. Mater. 15(18), 3507 (2003).

${ }^{13}$ X. Jiang, H. Huang, F. B. Prinz, and S. F. Bent, Chem. Mater. 20(12), 3897 (2008); C. Liu, Chih-Chieh Wang, Chi-Chung Kei, Yang-Chih Hsueh, and Tsong-Pyng Perng, Small 5(13), 1535 (2009).

${ }^{14} \mathrm{~J}$. W. Elam, C. A. Wilson, M. Schuisky, Z. A. Sechrist, and S. M. George, J. Vac. Sci. Technol., B 21(3), 1099 (2003).

${ }^{15}$ K. Tapily, J. Jakes, D. Stone, P. Shrestha, D. Gu, H. Baumgart, and A. Elmustafa, ECS Trans. 11(7), 123 (2007).

${ }^{16}$ Y. S. Jung, A. S Cavanagh, A. C. Dillon, M. D. Groner, S. M. George, and S.-H. Lee, J. Electrochem. Soc. 157(1), A75 (2010); Y. S. Jung, A. S. Cavanagh, L. A. Riley, Sun-Ho Kang, A. C. Dillon, M. D. Groner, S. M. George, and Se-Hee Lee, Adv. Mater. 22(19), 2172 (2010); S. K. Soni, B. W. Sheldon, X. Xiao, and A. Tokranov, Scr. Mater. 64(4), 307 (2011); X. Xiao, X. Huang, M. W. Verbrugge, and I. C. Halalay, US Patent No. 8,470,468 (12 February 2013).

${ }^{17}$ X. Xiao, P. Lu, and D. Ahn, Adv. Mater. 23(34), 3911 (2011).

${ }^{18} \mathrm{~K}$ Tapily, J. E. Jakes, D. S. Stone, P. Shrestha, D. Gu, H. Baumgart, and A. A. Elmustafa, J. Electrochem. Soc. 155(7), H545 (2008).

${ }^{19}$ M. K. Tripp, C. Stampfer, D. C. Miller, T. Helbling, C. F. Herrmann, C. Hierold, K. Gall, S. M. George, and V. M. Bright, Sens. Actuators, A 130, 419 (2006).

${ }^{20}$ H. J. Bauer and W. P. Mason, Physical Acoustics: Principles and Methods (Academic Press, 1965).

${ }^{21}$ D. Schneider, Th. Witke, Th. Schwarz, B. Schöneich, and B. Schultrich, Surf. Coat. Technol. 126(2), 136 (2000).

${ }^{22}$ T. S. Hickernell, F. M. Fliegel, and F. S. Hickernell, presented at the Proceedings of IEEE Ultrasonics Symposium, 1990 (unpublished).

${ }^{23}$ D. Schneider and T. Schwarz, Surf. Coat. Technol. 91(1), 136 (1997); D. Schneider, T. Schwarz, H.-J. Scheibe, and M. Panzner, Thin Solid Films 295(1), 107 (1997).

${ }^{24}$ M. D. Groner, F. H. Fabreguette, J. W. Elam, and S. M. George, Chem. Mater. 16(4), 639 (2004)

${ }^{25}$ S. W. Gaarenstroom, M. P. Balogh, M. C. Militello, R. A. Waldo, C. A. Wong, N. A. Kelly, T. L. Gibson, and M. D. Kundrat, Surf. Interface Anal. 37(4), 385 (2005); R. A. Waldo, M. C. Militello, and S. W. Gaarenstroom, Surf. Interface Anal. 20(2), 111 (1993).

${ }^{26}$ See supplementary material at http://dx.doi.org/10.1063/1.4892539 for Table S1 Young's modulus and Table S2 Area density measurements of the alumina coating as determined by EPMA.

${ }^{27}$ T. V. Perevalov, O. E. Tereshenko, V. A. Gritsenko, V. A. Pustovarov, A. P. Yelisseyev, C. Park, J. H. Han, and C. Lee, J. Appl. Phys. 108(1), 013501 (2010).

${ }^{28}$ A. Neubrand and P. Hess, J. Appl. Phys. 71(1), 227 (1992).

${ }^{29} \mathrm{~J}$. F. Shackelford and W. Alexander, CRC Materials Science and Engineering Handbook, 3rd ed. (CRC Press, New York, 2010).

${ }^{30}$ K. E. Petersen, Proc. IEEE 70(5), 420 (1982).

${ }^{31}$ C. F. Herrmann, F. W. DelRio, S. M. George, and V. M. Bright, presented at the MOEMS-MEMS Micro \& Nanofabrication, 2005 (unpublished). 